\title{
Molecular Characterization of the Glycated Plasma Membrane Calcium Pump
}

\author{
F.L. González Flecha ${ }^{1}$, P.R. Castello ${ }^{1}$, J.J. Gagliardino ${ }^{2}$, J.P.F.C. Rossi ${ }^{1}$ \\ ${ }^{1}$ Departamento de Química Biológica-IQUIFIB, Facultad de Farmacia y Bioquímica, Universidad de Buenos Aires—CONICET, Junín 956, \\ 1113 - Buenos Aires, Argentina \\ ${ }^{2}$ Centro de Endocrinología Experimental y Aplicada, Universidad Nacional de La Plata, CONICET, 60 y 120 , 1900 La Plata, Argentina
}

Received: 9 March 1999/Revised: 11 May 1999

\begin{abstract}
We have previously demonstrated (Diabetes 39:707-711, 1990) that in vitro glycation of the red cell $\mathrm{Ca}^{2+}$ pump diminishes the $\mathrm{Ca}^{2+}$-ATPase activity of the enzyme up to $50 \%$. Such effect is due to the reaction of glucose with lysine residues of the $\mathrm{Ca}^{2+}$ pump (Biochem. $J$. 293:369-375, 1993). The aim of this work was to determine whether the effect of glucose is due to a full inactivation of a fraction of the total population of $\mathrm{Ca}^{2+}$ pump, or to a partial inactivation of all the molecules. Glycation decreased the $V_{\max }$ for the ATPase activity leaving unaffected the apparent affinities for $\mathrm{Ca}^{2+}$, calmodulin or ATP. The apparent turnover was identical in both, the glycated and the native enzyme. Glycation decreased the $V_{\max }$ for the ATP-dependent but not for the calmodulin-activated phosphatase activities. Concomitantly with the inhibition, up to $6.5 \%$ of the lysine residues were randomly glycated. The probabilistic analysis of the relation between the enzyme activity and the fraction of nonmodified residues indicates that only one Lys residue is responsible for the inhibition. We suggest that glucose decreases the $\mathrm{Ca}^{2+}$-ATPase activity by reacting with one essential Lys residue probably located in the vicinity of the catalytic site, which results in the full inactivation of the enzyme. Thus, $\mathrm{Ca}^{2+}$-ATPase activity measured in erythrocyte membranes or purified enzyme preparations preincubated with glucose depends on the remaining enzyme molecules in which the essential Lys residue stays unglycated.
\end{abstract}

Key words: PMCA — Glycation - Phosphatase - Lys residues

\section{Introduction}

Nonenzymic glycosylation of proteins is a reaction that proceeds through several steps: the early ones (glycation) are reversible and develop in relatively short periods while the latter ones require longer times and become irreversible (Brownlee et al., 1986). Glycation of proteins is the consequence of the nucleophilic addition of their amino moiety to the carbonylic group of glucose. This reaction may occur on any side chain of the lysine residues exposed to the hydrophilic milieu (Ledl et al., 1989). In vivo, plasma and cellular proteins exposed to glucose undergo nonenzymic glycosylation (MacFarland et al., 1979; Miller, Gravallese \& Bunn, 1980). It has been claimed that the early and the end stages of this reaction are involved in the pathogenic mechanism of both, aging (Monnier, 1989) and the chronic complications of diabetes mellitus (Vlassara, Brownlee \& Cerami, 1986).

The erythrocyte $\mathrm{Ca}^{2+}$ pump is an integral membrane protein mainly corresponding to the hPMCA4b isoform (Strehler et al., 1990), which actively pumps out $\mathrm{Ca}^{2+}$ from the cytoplasm to the external medium. This molecule has 80 lysine residues outside the transmembrane regions, constituting potential targets for glycation. We have previously shown (González Flecha et al., 1990) that $\mathrm{Ca}^{2+}$-ATPase activity of erythrocytes obtained from poorly controlled diabetic patients is significantly lower than the one measured in those obtained from nondiabetic control. This effect was reproduced in vitro incubating either intact erythrocytes, erythrocyte membranes or purified calcium pump with glucose (González Flecha et al., 1990, 1993). The inhibition of the $\mathrm{Ca}^{2+}$-ATPase induced by in vitro glycation was enhanced by $\mathrm{pH}$ increase and the presence of phosphate; glucose can be replaced by other reducing sugars in the incubation me- 
dia-all known factors that affect the nonenzymic glycation process (Ellis, 1959). Preincubation of purified $\mathrm{Ca}^{2+}$ pump with $\left[6-{ }^{3} \mathrm{H}\right]$ glucose, showed similar kinetic properties for both, incorporation of radioactive glucose and the decrease in the enzyme activity, suggesting that inhibition is a consequence of the incorporation of glucose into the $\mathrm{Ca}^{2+}$-ATPase molecule. To shed further insight on this issue, we have currently studied how the glycation of the lysine residues of the $\mathrm{Ca}^{2+}$ pump leads to its inactivation.

\section{Materials and Methods}

\section{Chemicals}

All the chemicals used in this work were of analytical grade and purchased mostly from Sigma Chemical. D- $\left[6-{ }^{3} \mathrm{H}\right]$ glucose was purchased from DUPONT New England Nuclear (Boston, MA). $\left[\gamma^{-}{ }^{32} \mathrm{P}\right] \mathrm{ATP}$ was prepared according to the procedure of Glynn and Chappell (1964) except that no unlabeled orthophosphate was added to the incubation media. $\left[{ }^{32} \mathrm{P}\right]$-orthophosphate was provided by the Comisión Nacional de Energía Atómica (Argentina). Recently drawn human blood for the isolation of $\mathrm{Ca}^{2+}$-ATPase was obtained from the Hematology Section of the Hospital de Clínicas General San Martín (Argentina).

\section{ISOLATION OF MEMBRANES FROM HuMAN ERYTHROCYTES}

Red cells were washed 3 times with 10 volumes of cold $150 \mathrm{~mm} \mathrm{NaCl}$. Calmodulin-depleted erythrocyte membranes were prepared using a hypotonic solution according to the procedure described by Gietzen, Wüthrich and Bader (1981). The membrane suspension was frozen at $-80^{\circ} \mathrm{C}$ and stored until use. Protein concentration was determined according to the method of Lowry et al. (1951), modified by Peterson (1977).

\section{Purifichtion of The $\mathrm{Ca}^{2+}$ PumP}

$\mathrm{Ca}^{2+}$-ATPase was isolated in pure form by the calmodulin affinity chromatography procedure (Roufogalis \& Villalobo, 1989) as described previously (Castello et al., 1994), and found to be homogeneous by SDS-PAGE (single band at $M r 134000)$. The enzyme $(50 \mu \mathrm{g} / \mathrm{ml})$ was kept in storage buffer: $1 \mathrm{mg} / \mathrm{ml}$ asolectin, $0.5 \mathrm{mg} / \mathrm{ml} \mathrm{C}_{12} \mathrm{E}_{10}, 130$ mм KCl, 20 mм MOPS-K (pH 7.2 at $4^{\circ} \mathrm{C}$ ), 1 mM MgCl 2,2 mм EDTA, $2 \mathrm{mM} \mathrm{CaCl}_{2}, 2$ mM DTT. Purified enzyme was stored in liquid nitrogen until use.

\section{Glycation of Plasma Membrane $\mathrm{Ca}^{2+}$ Pump}

Erythrocyte membranes, or purified enzyme, were preincubated with $10 \mathrm{~mm}$ glucose for $2 \mathrm{hr}$ at $37^{\circ} \mathrm{C}$ in the presence of $40 \mathrm{~mm} \mathrm{NaH} \mathrm{NO}_{4} /$ $\mathrm{Na}_{2} \mathrm{HPO}_{4}$ (pH 7.4), and of an antiproteolytic cocktail: $3 \mathrm{~mm}$ sodium azide, $10 \mu \mathrm{M}$ leupepin, $100 \mu \mathrm{M}$ PMSF, $1 \mu \mathrm{g} / \mathrm{ml}$ aprotinin, $1 \mu \mathrm{M}$ pepstatin, $1 \mathrm{~mm}$ benzamidine, in order to prevent microbiological growth and proteolytic damage. In parallel, another aliquot of erythrocyte membrane - or purified enzyme - used as control was processed in the same manner replacing glucose by the noncarbonylic analogue mannitol.

\section{Measurement of $\mathrm{Ca}^{2+}$-ATPase Activity}

$\mathrm{Ca}^{2+}$-ATPase activity was measured at $37^{\circ} \mathrm{C}$ as described previously (Richards, Rega \& Garrahan, 1978), with some modifications. The incubation medium was (in $\mathrm{mM}$ ): $120 \mathrm{KCl} ; 30$ Tris- $\mathrm{HCl}$ (pH 7.4); 4 $\mathrm{MgCl}_{2} ; 1$ EGTA; $1 \mathrm{CaCl}_{2}\left(\left[\mathrm{Ca}^{2+}\right.\right.$ free $\left.]=36 \mu \mathrm{M}\right), 1 \mathrm{mg} / \mathrm{ml}$ asolectin, 0.5 $\mathrm{mg} / \mathrm{ml} \mathrm{C}_{12} \mathrm{E}_{10}$ and $2 \mathrm{mM}\left[\gamma^{-}{ }^{32} \mathrm{P}\right] \mathrm{ATP}$. The protein concentration was $100 \mu \mathrm{g} / \mathrm{ml}$ (membrane assay) or $1 \mu \mathrm{g} / \mathrm{ml}$ (purified enzyme assay). $\mathrm{Ca}^{2+}$-ATPase activity was taken as the difference between the activity measured in the above medium and that measured in the same medium without calcium. The release of $\left[{ }^{32} \mathrm{Pi}\right]$ from the nucleotide was estimated according to the procedure of Richards et al. (1978) with some modifications (González Lebrero et al., personal communication). Ionic $\mathrm{Ca}^{2+}$ concentration in the incubation media was measured using a selective $\mathrm{Ca}^{2+}$-electrode, as described by Rossi, Garrahan and Rega (1986).

\section{Measurement of Phosphatase Activity}

ATP-dependent phosphatase activity of the erythrocyte membranes was assayed at $37^{\circ} \mathrm{C}$ in a medium containing (in mM): $120 \mathrm{KCl} ; 30$ Mops-KOH (pH 7.4); $6.25 \mathrm{MgCl}_{2} ; 1$ ouabain. 1 EGTA; $1.1 \mathrm{CaCl}_{2}$ $\left(\left[\mathrm{Ca}^{2+}{ }_{\text {free }}\right]=140 \mu \mathrm{M}\right)$ and $0.5 \mathrm{ATP}$. The protein concentration was $150 \mu \mathrm{g} / \mathrm{ml}$. Calmodulin-dependent phosphatase activity of the erythrocyte membranes was assayed at $37^{\circ} \mathrm{C}$ in a medium containing (in mM): $120 \mathrm{KCl} ; 30$ Mops-KOH (pH 7.4); $6.25 \mathrm{MgCl}_{2} ; 1$ ouabain. 1 EGTA; $0.84 \mathrm{CaCl}_{2}\left(\left[\mathrm{Ca}^{2+}{ }_{\text {free }}\right]=1.3 \mu \mathrm{M}\right)$ and $0.5 \mathrm{ATP}$. Both phosphatase activities were evaluated by measuring the release of $\mathrm{p}$ nitrophenylphosphate as previously described (Donnet et al., 1998).

\section{Measurement of Phosphoprotein Formation}

$\mathrm{Ca}^{2+}$ ATPase phosphorylation was performed using and adaptation of the procedure originally employed for erythrocyte membranes (Rega \& Garrahan, 1975) that allowed a high precision measure. Thus, purified $\mathrm{Ca}^{2+}$ pump was incubated at $0^{\circ} \mathrm{C}$ in the presence of $1 \mathrm{mg} / \mathrm{ml}$ asolectin, $0.5 \mathrm{mg} / \mathrm{ml} \mathrm{C}_{12} \mathrm{E}_{10}, 120 \mathrm{~mm} \mathrm{KCl}, 30 \mathrm{~mm}$ MOPS-K (pH 7.2 at $4^{\circ} \mathrm{C}$ ), 4 mM $\mathrm{MgCl}_{2}, 1 \mathrm{~mm}$ EGTA, $1 \mathrm{~mm} \mathrm{CaCl}_{2}, 2$ mм DTT. The reaction was started by the addition of $10 \mu \mathrm{M}\left[{ }^{32} \mathrm{P}\right] \mathrm{ATP}$ to the reaction medium. After $45 \mathrm{sec}$ the reaction was stopped by the addition of $7 \%$ TCA, 0.1 mM ATP and $50 \mathrm{~mm} \mathrm{H}_{3} \mathrm{PO}_{4}$. The mixture was filtered through Millipore membranes (pore size $0.2 \mu \mathrm{m}$ ) and washed three times with $7 \%$ TCA, $50 \mathrm{~mm} \mathrm{H}_{3} \mathrm{PO}_{4}$. The membranes were dried and transferred to counting vials. Radioactivity was determined by liquid scintillation using $0.4 \%$ PPO, $0.02 \%$ POPOP in toluene as scintillation solution. The $\left[{ }^{32} \mathrm{P}\right]$ ATP incorporation is a measure of the number of available phosphorylation sites (Muallem \& Karlish, 1981, 1983).

\section{MeAsurement of Glucose InCORPoration to THE $\mathrm{Ca}^{2+}$ PUMP}

Incorporation of glucose to the purified pump was determined as described previously (González Flecha et al., 1993). Purified pump (20 $\mu \mathrm{g} / \mathrm{ml}$ ) was incubated during different times at $37^{\circ} \mathrm{C}$ in a media containing $10 \mathrm{~mm}\left[6-{ }^{3} \mathrm{H}\right]$ glucose (specific radioactivity $3000 \mathrm{dpm} / \mathrm{nmol}$ ) in the presence of $40 \mathrm{~mm} \mathrm{NaH} \mathrm{PO}_{4} / \mathrm{Na}_{2} \mathrm{HPO}_{4}$ ( $\mathrm{pH} 7.4$ ), and the antiproteolytic cocktail. At different times, aliquots $(200 \mu \mathrm{l})$ were removed and mixed with a cold solution of $100 \mathrm{~mm}$ glucose. After isotopic dilution, enzyme was precipitated with 7\% TCA and filtered through Sartorius membrane filters $(0.20 \mu \mathrm{m}$ pore size $)$. The filters were 
washed thrice with $15 \mathrm{ml}$ of an ice-cold solution of $10 \mathrm{~mm}$ glucose-15 mм Mops- $\mathrm{KOH} \mathrm{pH} 7.4$, dried and transferred to counting vials.

\section{Polyacrylamide Gel Electrophoresis}

Electrophoresis was carried out according to the Tris/tricine SDS/ PAGE method (Schägger \& von Jagow, 1987). Peptide bands were stained with colloidal Brilliant Blue G (Neuhoff et al., 1988). Accurate quantification of peptide amount was performed by densitometric analysis (González Flecha, 1996). The gel was dried and cut into slices $0.8 \mathrm{~mm}$ wide. After soaking each slice in hydrogen peroxide and incubation overnight at $50^{\circ} \mathrm{C}$ (Tishler \& Epstein, 1968), the radioactivity was determined by liquid scintillation counting. Subtracting the average radioactivity for gel slices containing no peptide material performed a background correction. The radioactivity associated with each peptide was measured by estimating the area under a Gaussian function fitted to the radioactivity distribution.

\section{ANALYSIS OF THE DATA}

All measurements were performed by duplicate or triplicate. Experiments presented in Results were chosen as representative of at least two independent experiments. The equations were fitted to the experimental data by a nonlinear regression procedure based on the GaussNewton algorithm (Rossi, 1987; Seber \& Wild, 1989). The dependent variable was assumed to be homoscedastic (constant variance) and the independent variable to have negligible error. The "best fitting equation" was considered as that which gave the minimal standard deviation of the regression and the least biased fit. Parameters were expressed as mean value \pm standard error.

\begin{tabular}{|c|c|}
\hline \multicolumn{2}{|c|}{ ABBREVIATIONS } \\
\hline $\mathrm{C}_{12} \mathrm{E}_{10}$ & polyoxy-ethylene 10 lauryl ether \\
\hline DTT & 1,4-dithiothreitol \\
\hline EGTA & $\begin{array}{l}\text { ethylene glycol bis(aminoethyl ether)-N, } \mathrm{N}, \mathrm{N}^{\prime}, \mathrm{N}^{\prime} \text { - } \\
\text { tetraacetic acid }\end{array}$ \\
\hline FITC & fluorescein isothiocyanate \\
\hline hPMCA4b & $\begin{array}{l}\text { isoform } 4 \mathrm{~b} \text { of the human plasma membrane calcium } \\
\text { pump }\end{array}$ \\
\hline PMSF & phenyl methyl sulfonyl fluoride \\
\hline $\mathrm{pNPP}$ & p-nitrophenyl phosphate \\
\hline PPO & 2,5 diphenyloxazole \\
\hline POPOP & 1,4-bis[5-phenyl-2-oxazolyl]bencene \\
\hline MOPS & 3-(N-morpholino)-propanesulfonic acid \\
\hline SDS-PAGE & $\begin{array}{l}\text { polyacrylamide gel electrophoresis in the presence of } \\
\text { sodium dodecyl sulfate }\end{array}$ \\
\hline TCA & trichoroacetic acid \\
\hline
\end{tabular}

\section{Results}

\section{Effect of Plasma Membrane Glycation Upon Different $\mathrm{Ca}^{2+}$-ATPase Kinetic Parameters}

Glycation of the pump may occur to lysine side chains involved in the conformation of either the catalytic or the modulatory sites. By altering these amino acid residues, the forces holding the substrate or modulators in place are modified and hence the kinetic behavior of the en-

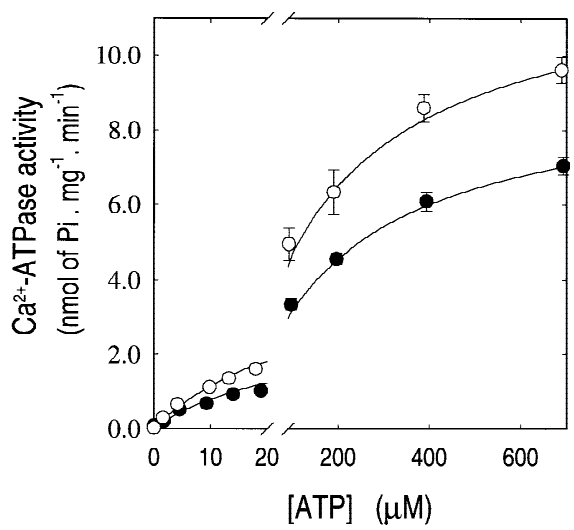

Fig. 1. $\mathrm{Ca}^{2+}$-ATPase activity in glycated membranes as a function of ATP concentration. Preincubation of membranes was carried out in the presence of $10 \mathrm{~mm}$ of either glucose $(\mathbf{O})$ or mannitol $(\bigcirc) . \mathrm{Ca}^{2+}$-ATPase activity was measured as described in Materials and Methods in a media with $\left[\mathrm{Ca}^{2+}\right]_{\text {free }}=36 \mu \mathrm{M}$ and $[\mathrm{ATP}]$ variable $(1 \mu \mathrm{M}-2 \mathrm{mM})$. The continuous line is the graphical representation of Eq. 1. The best fit was obtained for the following parameter values:

\begin{tabular}{lllll}
\hline $\begin{array}{l}\text { Glucose } \\
\text { concentration } \\
(\mathrm{mM})\end{array}$ & $\begin{array}{l}V_{\max _{H}} \\
(\mathrm{nmol} \cdot \\
\left.\mathrm{mg}^{-1} \cdot \mathrm{min}^{-1}\right)\end{array}$ & $\begin{array}{l}\mathrm{Km}_{H} \\
(\mu \mathrm{M})\end{array}$ & $\begin{array}{l}V_{\max _{L}} \\
(\mathrm{nmol} \cdot \\
\left.\mathrm{mg}^{-1} \cdot \mathrm{min}^{-1}\right)\end{array}$ & $\begin{array}{l}\mathrm{Km}_{L} \\
(\mu \mathrm{M})\end{array}$ \\
\hline 0 & $1.7 \pm 0.2$ & $10.2 \pm 1.4$ & $10.4 \pm 0.7$ & $242 \pm 38$ \\
10 & $1.1 \pm 0.1$ & $11.3 \pm 1.7$ & $8.2 \pm 0.3$ & $265 \pm 24$ \\
\hline
\end{tabular}

zyme might be affected. Modulation of the plasma membrane $\mathrm{Ca}^{2+}$-ATPase by ATP, $\mathrm{Ca}^{2+}$ and calmodulin are well characterized processes, therefore its evaluation in glycated membranes could be an useful tool to investigate the effects of glycation.

All the experiments reported in this paper include controls with polyols. A polyol, rather than a buffer control, is especially useful since both, sugars and polyols, increase the thermal stability of proteins through strengthening of the pairwise hydrophobic interaction between hydrophobic groups (Back, Oakenfull \& Smith, 1979).

Figure 1 shows the dependence of the $\mathrm{Ca}^{2+}$-ATPase activity $\left(v_{\text {ATPase }}\right)$ on the ATP concentration in glycated and control membranes. Equation 1, which represents the biphasic response of the $\mathrm{Ca}^{2+}$-ATPase to ATP (Richards et al., 1978), was fitted to the experimental data.

$v_{\text {ATPase }}=\frac{V_{\max _{H}}[\mathrm{ATP}]}{K m_{H}+[\mathrm{ATP}]}+\frac{V_{\max _{L}}[\mathrm{ATP}]}{K m_{L}+[\mathrm{ATP}]}$

Results in Fig. 1 show that preincubation with glucose significantly decreased $V_{\max }$ corresponding to ATP hydrolysis in the high affinity site $(P<0.01)$ and in the low affinity site $(P<0.02)$. Conversely, no significant differences were found in $K_{m}$ values for each site between control and glycated membranes. 


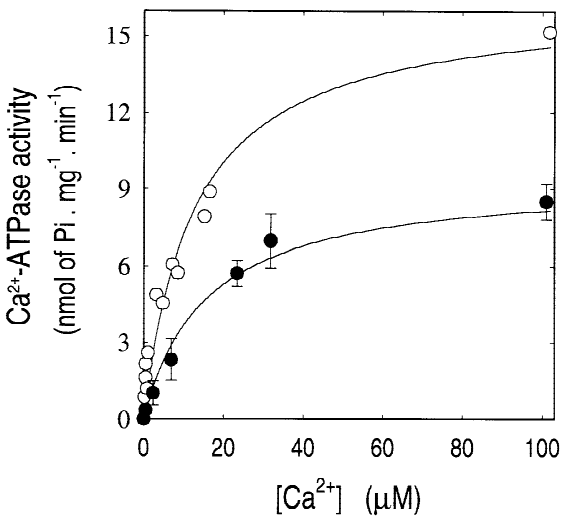

Fig. 2. Effect of $\mathrm{Ca}^{2+}$ concentration on $\mathrm{Ca}^{2+}$-ATPase activity in glycated membranes. Membranes were preincubated with $10 \mathrm{~mm}$ of either glucose $(\bullet)$ or mannitol $(\bigcirc)$. Enzyme activity was measured as described in Materials and Methods in a media with [ATP] $=2 \mathrm{~mm}$ and $\left[\mathrm{Ca}^{2+}\right]_{\text {free }}$ variable $(0.5$ to $100 \mu \mathrm{M})$. The continuous lines are the graphical representation of Eq. 2 . The parameter values providing the best fit were:

\begin{tabular}{lll}
\hline $\begin{array}{l}\text { Glucose } \\
\text { concentration } \\
(\mathrm{mM})\end{array}$ & $\begin{array}{l}V_{\max } \\
\left(\mathrm{nmol} \cdot \mathrm{mg}^{-1} \cdot \mathrm{min}^{-1}\right)\end{array}$ & $\begin{array}{l}K_{C a} \\
(\mu \mathrm{M})\end{array}$ \\
\hline 0 & & \\
10 & $16.4 \pm 1.3$ & $12.6 \pm 2.6$ \\
& $10.4 \pm 0.6$ & $15.5 \pm 4.8$
\end{tabular}

The dependence of the $\mathrm{Ca}^{2+}$-ATPase activity on the $\mathrm{Ca}^{2+}$ concentration in control and glycated membranes is shown in Fig. 2. As described previously (Schatzmann \& Roelofsen, 1977), the activation of $\mathrm{Ca}^{2+}$-ATPase by $\mathrm{Ca}^{2+}$ in the absence of calmodulin follows a MichaelisMenten-like kinetics (Eq. 2).

$v_{\text {ATPase }}=\frac{V_{\max _{C a}}\left[\mathrm{Ca}^{2+}\right]}{K_{C a}+\left[\mathrm{Ca}^{2+}\right]}$

Preincubation with glucose significantly decreased $(P<0.01)$ the maximum rate of ATP hydrolysis for $\mathrm{Ca}^{2+}$ activation. Differences in $K_{C a}$ between control and glycated membranes were not significant.

One of the most typical properties of the plasma membrane $\mathrm{Ca}^{2+}$ pump is its ability to directly interact with calmodulin. Calmodulin increases the apparent affinity for $\mathrm{Ca}^{2+}$ and the turnover number of the phosphoenzyme (Carafoli, 1991). The kinetic behavior may be described as a hyperbolic increment of the activity beginning on a basal activity in the absence of calmodulin (Caride et al., 1990) as described by Eq. 3:

$v_{\text {ATPase }}=v_{O}+\frac{V_{\max _{C a M}}[\mathrm{CaM}]}{K_{C a M}+[\mathrm{CaM}]}$

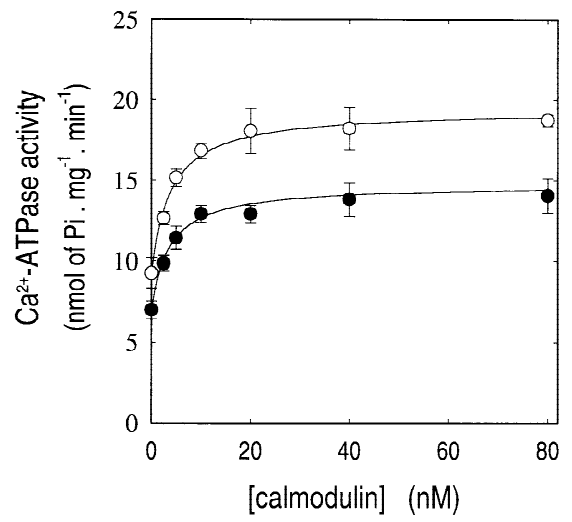

Fig. 3. Activation by calmodulin of $\mathrm{Ca}^{2+}$-ATPase in glycated membranes. Preincubation of membranes were carried in the presence of 10 mM of either glucose $(\bullet)$ or mannitol $(\bigcirc)$. $\mathrm{Ca}^{2+}$-ATPase activity was measured in a media with $\left[\mathrm{Ca}^{2+}\right]_{\text {free }}=36 \mu \mathrm{M},[\mathrm{ATP}]=2 \mathrm{~mm}$ and 0 to $80 \mathrm{~nm}$ calmodulin as described in Materials and Methods. The continuous lines are the graphical representation of Eq. 3. The parameter values resulting from the nonlinear fitting of this equation to the experimental data were:

\begin{tabular}{llrl}
\hline $\begin{array}{l}\text { Glucose } \\
\text { concentration } \\
(\mathrm{mM})\end{array}$ & $\begin{array}{l}v_{o} \\
(\mathrm{nmol} \cdot \\
\left.\mathrm{mg}^{-1} \cdot \mathrm{min}^{-1}\right)\end{array}$ & $\begin{array}{l}V_{\max } \\
\left(\mathrm{nmol} \cdot \mathrm{mg}^{-1} \cdot \mathrm{min}^{-1}\right)\end{array}$ & $\begin{array}{l}K_{\text {CaM }} \\
(\mathrm{nM})\end{array}$ \\
\hline 0 & $9.14 \pm 0.57$ & $10.24 \pm 0.64$ & $3.8 \pm 0.8$ \\
10 & $6.97 \pm 0.4$ & $7.79 \pm 0.57$ & $3.7 \pm 1.0$ \\
\hline
\end{tabular}

Figure 3 shows the effect of the plasma membrane glycation on the $\mathrm{Ca}^{2+}$-ATPase-calmodulin interaction. Preincubation with glucose significantly decreased $v_{o}(P$ $<0.01)$ and $V_{\max }(P<0.02)$, while the differences in $K_{C a M}$ were not significant. The relative inactivation of the $\mathrm{Ca}^{2+}$-ATPase, measured in the presence or in the absence of calmodulin shows nearly the same value.

\section{Effect of Plasma Membrane Glycation on Phosphatase Activities of The $\mathrm{Ca}^{2+}$ Pump}

After glycation of erythrocyte membranes, ATPdependent and calmodulin-dependent phosphatase activities were measured as described in Materials and Methods. The dependence of the phosphatase activity on the pNPP concentration in control and glycated membranes is shown in Fig. 4. As described previously (Rossi \& Caride, 1991), this dependence could be described by Eq. 4.

$v_{p N P P a s e}=\frac{V_{\max _{p N P P(C a M, A T P)}}}{\left(1+\frac{K m_{(\mathrm{CaM}, A T P)}}{[\mathrm{pNPP}]}\right)^{2}}$

Preincubation with glucose significantly decreased $(P<$ 

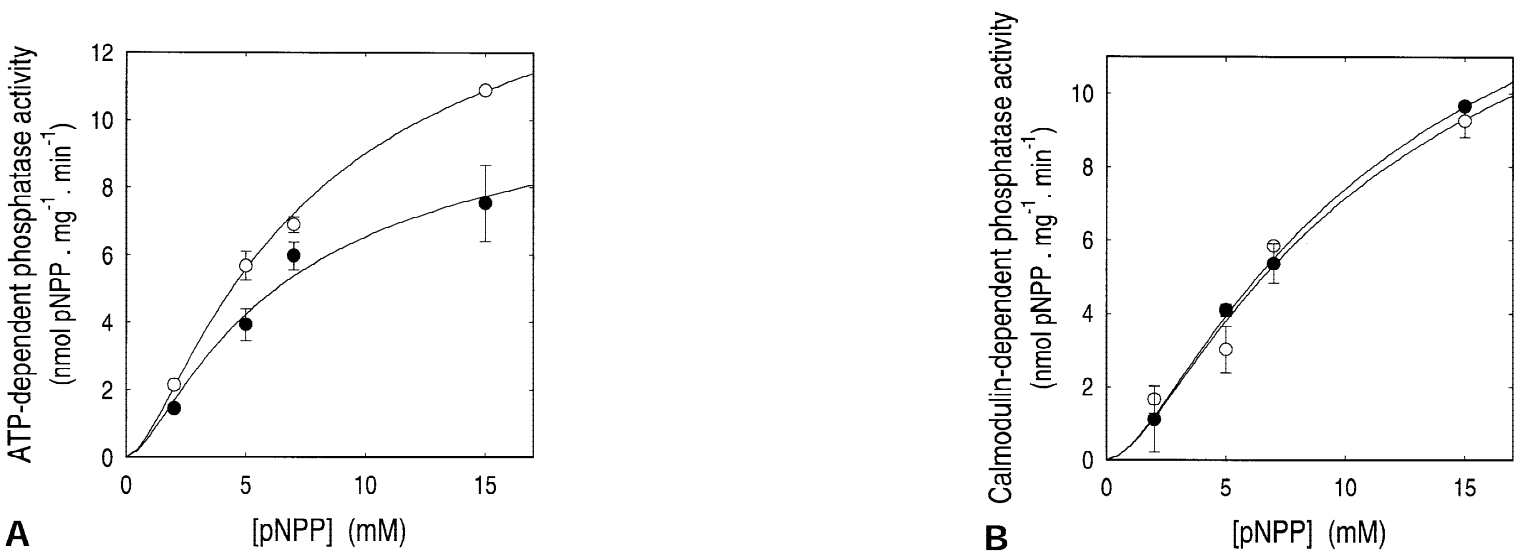

Fig. 4. $\mathrm{Ca}^{2+}$-pNPPase activity in glycated membranes as a function of pNPP concentration. Preincubations of membranes were carried out in the presence of $10 \mathrm{mM}$ of either glucose $(\Theta)$ or mannitol $(\bigcirc)$. ATP-dependent $(A)$ and calmodulin-dependent $(B) \mathrm{Ca}^{2+}$-phosphatase activities were measured as described in Materials and Methods as a function of [pNPP] (in the range $0-15 \mathrm{~mm}$ ). The continuous line is the graphical representation of Eq. 4. The best fit was obtained for the following parameter values:

\begin{tabular}{|c|c|c|c|c|}
\hline $\begin{array}{l}\text { Glucose } \\
\text { concentration (mM) }\end{array}$ & $\begin{array}{l}V_{\max _{p N P P, A T P}} \\
\left(\mathrm{nmol} \cdot \mathrm{mg}^{-1} \cdot \min ^{-1}\right)\end{array}$ & $\begin{array}{l}K m_{A T P} \\
(\mathrm{mM})\end{array}$ & $\begin{array}{l}V_{\max _{p N P P, C a M}} \\
\left(\mathrm{nmol} \cdot \mathrm{mg}^{-1} \cdot \min ^{-1}\right)\end{array}$ & $\begin{array}{l}K m_{C a M} \\
(\mathrm{mM})\end{array}$ \\
\hline 0 & $16.9 \pm 0.9$ & $3.7 \pm 0.3$ & $18 \pm 3$ & $5.9 \pm 1.3$ \\
\hline
\end{tabular}

0.005) the maximum rate of ATP-dependent pNPP hydrolysis but did not modify the $V_{\max _{p N P P}}$ for the calmodulin-dependent phosphatase. Differences in $K_{m}$ between control and glycated membranes were nonsignificant for both activities.

\section{Effect of Glycation of the $\mathrm{Ca}^{2+}$ Pump Upon the Turnover of THE PHOSPHOENZYME}

Purified $\mathrm{Ca}^{2+}$-ATPase was incubated $2 \mathrm{hr}$ at $37^{\circ} \mathrm{C}$ in a media containing $10 \mathrm{~mm}$ glucose or mannitol (control), $40 \mathrm{mM} \mathrm{NaH}_{2} \mathrm{PO}_{4} / \mathrm{Na}_{2} \mathrm{HPO}_{4}$ ( $\mathrm{pH}$ 7.4), and the antiproteolytic cocktail. After incubation, samples were then dialyzed against $50 \mathrm{~mm}$ Tris- $\mathrm{H}_{3} \mathrm{PO}_{4}\left(\mathrm{pH} 7.2\right.$ at $\left.25^{\circ} \mathrm{C}\right)$ and analyzed by SDS-PAGE. The integrity of the pump was conserved as judged by the appearance of a single stained band at Mr 134000. This result indicates that glycation produce neither fragmentation nor formation of SDS-stable aggregates of the protein.

The steady-state $\mathrm{Ca}^{2+}$ ATPase activity $\left(v_{\text {ATPase }}\right)$ and phosphoenzyme concentration ([EP]) were measured as described in Materials and Methods. The ratio between $v_{\text {ATPase }}$ and [EP] depends exclusively on the rate coefficients for the conformational changes and hydrolysis of the phosphoenzyme (Schwarzbaum et al., 1995). Therefore, the evaluation of this ratio in glycated $\mathrm{Ca}^{2+}$ pump provides information about some reaction steps different from those examined by the kinetic parameters described in the previous section. The Table shows the results of
Table 1. Effect of glycation on the steady-state EP concentration and velocity of ATP hydrolisis

\begin{tabular}{llll}
\hline $\begin{array}{l}\text { Glucose } \\
\text { concentration } \\
(\mathrm{mm})\end{array}$ & $\begin{array}{l}{\left[\begin{array}{l}\left.{ }^{32} \mathrm{P}\right]- \text { bound EP } \\
\left(\mathrm{nmol} \cdot \mathrm{mg}^{-1}\right)\end{array}\right.} \\
\end{array}$ & $\begin{array}{l}v \text { of ATP } \\
\text { hydrolysis }(\mathrm{nmol} \cdot \\
\left.\mathrm{mg}^{-1} \cdot \mathrm{sec}^{-1}\right)\end{array}$ & $\begin{array}{l}v /\left[{ }^{32} \mathrm{PP}\right]-\text { bound } \\
\left(\mathrm{sec}^{-1}\right)\end{array}$ \\
\hline 0 & $1.8 \pm 0.2$ & $20.3 \pm 1.4$ & $11.3 \pm 2.0$ \\
10 & $1.1 \pm 0.1$ & $11.0 \pm 0.4$ & $10.0 \pm 1.3$
\end{tabular}

these experiments and the relationship between the remaining phosphoenzyme level and $\mathrm{Ca}^{2+}$-ATPase activity. Preincubation with glucose significantly decreased $\mathrm{Ca}^{2+}$-ATPase activity $(P<0.005)$ and phosphoenzyme concentration $(P<0.05)$ but nonsignificant differences were found in the turnover of the phosphoenzyme.

\section{GluCOSE InCORPORATION INTO THE $\mathrm{Ca}^{2+}$ PuMP AND ITS EFFECTS ON $\mathrm{Ca}^{2+}$-ATPASE ACTIVITY}

The measurement of glucose incorporation to the $\mathrm{Ca}^{2+}$ pump and its relation with the loss of activity allows us to explore the structural changes associated with the inhibition. Because of the specific radioactivity of the $\left[6-{ }^{3} \mathrm{H}\right]$ glucose employed for the glycation of the pump, the radioactivity that remains bound to the protein after glycation is a measure of the number of moles of glucose bound per mole of $\mathrm{Ca}^{2+}$ pump. Since the stoichiometry of glycation is one mole of glucose per mole of amino 


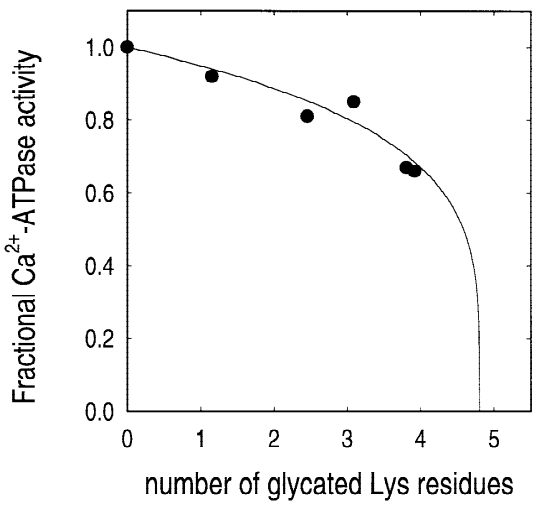

Fig. 5. $\mathrm{Ca}^{2+}$-ATPase activity as a function of the number of glycated Lys residues. Purified $\mathrm{Ca}^{2+}$ pump was incubated at $37^{\circ} \mathrm{C}$ in a media containing $10 \mathrm{~mm}$ glucose or mannitol (control). At different times, samples were removed and cooled in an ice bath. $\mathrm{Ca}^{2+}$-ATPase activity, expressed as the fraction of the activity of the corresponding control, and glucose incorporation were measured as described in Materials and Methods. The continuous line is the graphical representation of Eq. 4. The best fit value of $G L_{\infty}$, was $4.7 \pm 0.8$.

group, this indicates the number of moles of glycated lysine residues per mole of $\mathrm{Ca}^{2+}$ pump.

Figure 5 shows the relationship between the remaining fractional $\mathrm{Ca}^{2+}$-ATPase activity $\left(v / v_{0}\right)$ and the average number of glycated lysine residues per molecule of the pump $(G L)$. Since glucose incorporation into the pump and the decrease of its activity, follow a pseudofirst-order kinetic (González Flecha et al., 1993) the relationship mentioned above may be described by:

$\frac{G L}{G L_{\infty}}=1-\left(\frac{\nu}{v_{0}}\right)^{\gamma}$

Where $G L_{\infty}$ is the total number of lysine residues that could react with glucose concomitantly with the inactivation, and $\gamma$ is a factor that includes the kinetic coefficients of both processes. The value of $G L_{\infty}$, obtained by fitting of Eq. 4 to the experimental data, is 4.7 \pm 0.8 , indicating that, on average, up to 5 lysine residues per enzyme molecule are bound to the pump during glycation.

To determine the number of glycated lysine residues responsible for the inhibition, we used a particular form of the analysis proposed by Tsuo (1962). The validity of this method has been critically analyzed (Horiike \& McCormick, 1979). A brief description of the application of this analysis is given in the Appendix. Equation 6 shows the relation between the relative activity $\left(v_{r}\right)$ and the number of unglycated residues $(n \cdot x)$ :

$\ln \left[\frac{n \cdot x}{v_{r}{ }^{1 / i}}-p\right]=\ln (n-p)+\frac{(\alpha-1)}{i} \cdot \ln v_{r}$

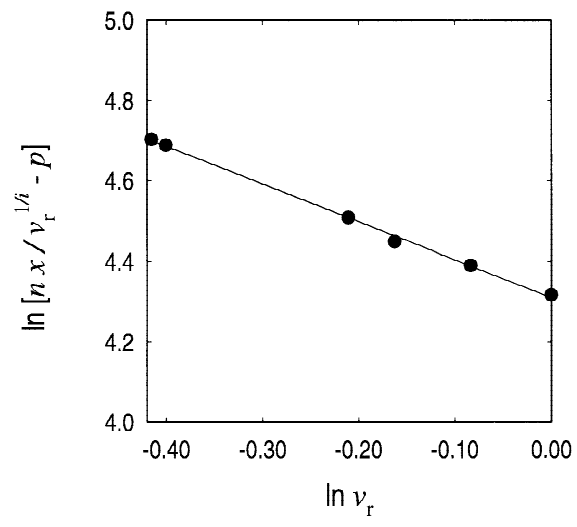

Fig. 6. Plot of $\ln \left(n \cdot x / v_{r}{ }^{1 / i}-p\right)$ against $\ln v_{r}$. The remnant ATPase activity after glycation $\left(v_{r}\right)$ and the fraction of nonglycated residues $(x)$ were calculated from the experimental data shown in Fig. 4 ( $v_{r}$ are the $\mathrm{y}$-values and $x$ are $1-\mathrm{x}$-values $/ n$ ). The straight line is the graphical representation of Eq. 5 with $n=80 ; p=5$ and $i=1$. From the slope, a value of $\alpha=0.06 \pm 0.02$ was obtained.

Where $n$ is the total number of lysine residues in the pump, $x$ is the fraction of nonglycated residues, $p$ is the total number of lysine residues that reacts with glucose concomitantly with the inactivation $\left(G L_{\infty}\right.$ in Fig. 5) and $i$ is the number of lysine residues responsible for the inhibition.

For $n=80$ and $p=5$, Eq. 4 gave a satisfactory straight line for $i=1$ (Fig. 6). Other values of $i$ result in nonlinear plots.

\section{RADiOACTIVITY INCORPORATION INTO THE PROTEOLYTIC Peptides from $\left[6-{ }^{3} \mathrm{H}\right]$-Glucose Labeled $\mathrm{Ca}^{2+}$ PumP}

To assess the extent of glycation into different regions of the pump, we proceeded to examine the incorporation of the label to proteolytic fragments of the pump. Glycated pump ( 2 moles of [ $\left.6{ }^{3} \mathrm{H}\right]$-glucose per mole of pump) was digested for $2 \mathrm{hr}$ at $25^{\circ} \mathrm{C}$ with $200 \mathrm{ng} / \mathrm{ml}$ of V8 protease in the presence of $0.8 \%$ SDS. The resulting peptides were separated by SDS-PAGE as described in Materials and Methods.

Digestion of the pump in this condition produced three complementary fragments of Mr 58000 (A), 40000 (B) and $38000(\mathrm{C})$, spanning the whole sequence of the pump (Castello et al., 1994). Fragments A and B include the $\mathrm{C}$ - and $\mathrm{N}$-termini respectively, whereas the $\mathrm{C}$ fragment corresponds to a major central portion of this protein. These three fragments were labeled with $\left[6-{ }^{3} \mathrm{H}\right]-$ glucose (Fig. 7). Every one of them showed comparable specific incorporation of the label (about $5000 \mathrm{dpm} / \mu \mathrm{g}$ of peptide).

Extensive digestion of the labeled pump with 500 $\mathrm{ng} / \mathrm{ml}$ of V8 protease in the presence of $0.8 \%$ of SDS for $18 \mathrm{hr}$ produces five new peptides of $\mathrm{Mr} 38000,25000$, 


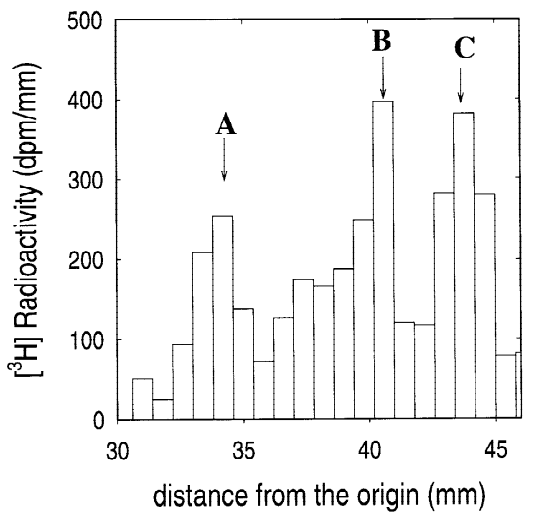

$\begin{array}{ccc}70000 & 50000 & 35000 \\ M r & \end{array}$

Fig. 7. Electrophoretic analysis of peptides obtained after V8 protease digestion of the plasma membrane calcium pump labeled with $\left[{ }^{3} \mathrm{H}\right] \mathrm{Glu}-$ cose. Purified $\mathrm{Ca}^{2+}$-ATPase $(50 \mu \mathrm{g}$ of protein $/ \mathrm{ml})$ was incubated during $2 \mathrm{hr}$ at $37^{\circ} \mathrm{C}$ in a media containing $10 \mathrm{~mm}\left[6-{ }^{3} \mathrm{H}\right]$ glucose (specific radioactivity $300 \mathrm{dpm} / \mathrm{pmol}$ ) in the presence of $40 \mathrm{~mm} \mathrm{NaH} \mathrm{PO}_{4} /$ $\mathrm{Na}_{2} \mathrm{HPO}_{4}$ (pH 7.4), and the antiproteolytic cocktail. The sample was then dialyzed against $50 \mathrm{~mm}$ Tris- $\mathrm{H}_{3} \mathrm{PO}_{4}\left(\mathrm{pH} 7.2\right.$ at $\left.25^{\circ} \mathrm{C}\right)$ and digested for $4 \mathrm{hr}$ with $200 \mathrm{ng} / \mathrm{ml}$ of $\mathrm{V} 8$ protease in the presence of $0.8 \%$ of SDS. The reaction was stopped by the addition of 3,4-dichloroisocoumarin up to a final concentration of $25 \mu \mathrm{M}$. The peptide mixture was separated by SDS-PAGE and the distribution of radioactivity in the gel was determined as described in Materials and Methods. Arrows indicate the proteolytic fragments A through $\mathrm{C}$.

20000, 15000 and 10000 arising mainly from the Nterminal half of the molecule (Castello et al., 1997). The specific incorporation of the label was about $5000 \mathrm{dpm} /$ $\mu \mathrm{g}$ of peptide for all these peptides (data not shown). Again, no selective reaction of $\left[6-{ }^{3} \mathrm{H}\right]$-glucose with any of these peptides was readily apparent.

\section{Discussion}

Glycation of the Calcium Pump Produces the Full INACTIVATION OF A Fraction OF MOLECULES

Previous results have shown that exposure of red cell membranes to high concentrations of glucose, both in vivo (González Flecha et al., 1990) and in vitro (González Flecha et al., 1990, 1993), decreases their $\mathrm{Ca}^{2+}$ ATPase activity up to $50 \%$ of the control activity. There are at least two possible explanations for this partial inactivation of the enzyme: (i) glycation might reach the steady state in which the $50 \%$ of the $\mathrm{Ca}^{2+}$-ATPase molecules are inactivated; thus, glucose fully inactivates only a fraction of the total number of $\mathrm{Ca}^{2+}$ pump molecules, and (ii) glucose might partially inactivate all the
$\mathrm{Ca}^{2+}$ pump molecules, producing a modified enzyme with a decreased turnover. Our results showed that glycation of the plasma membrane $\mathrm{Ca}^{2+}$ pump significantly decreases the maximal rate for the regulation of the $\mathrm{Ca}^{2+}$ ATPase activity by ATP (Fig. 1), $\mathrm{Ca}^{2+}$ (Fig. 2), and calmodulin (Fig. 3). However, glycation does not affect the apparent affinities for these modulators of the $\mathrm{Ca}^{2+}$ ATPase activity.

The decrease in $\mathrm{Ca}^{2+}$-ATPase activity after glycation is accompanied by an identical decrease of the phosphoenzyme concentration (Table). Therefore, the turnover of the phosphoenzyme was identical in both, glycated and nonglycated control enzymes. Glycation of the pump not only affects the $\mathrm{Ca}^{2+}$-ATPase activity but also, and to the same degree, the active $\mathrm{Ca}^{2+}$ transport rate (González Flecha et al., 1993) and the maximal rate for the regulation of the ATP-dependent phosphatase by pNPP (Fig. 4a). All these quantities share the same reaction scheme (Donnet et al., 1998).

Our results show that glycation does not affect the $V_{\max }$ for the calmodulin-dependent hydrolysis of pNPP, which probably involves a futile cycle that hydrolyzes pNPP but elicit neither $\mathrm{Ca}^{2+}$ transport nor ATP hydrolysis (Donnet et al., 1998).

According to these data, and because of their interpretation in terms of the kinetic coefficients of the elementary steps (Segel, 1975), a consistent picture emerges for the effect of glycation on the $\mathrm{Ca}^{2+}$ pump. All the kinetic quantities modified by glycation: the maximal rate for both, the regulation of $\mathrm{Ca}^{2+}$-ATPase and the ATP-dependent phosphatase activities, the concentration of phosphorylated enzyme, and the rate of active $\mathrm{Ca}^{2+}$ transport, may be expressed as the product of total amount of active $\mathrm{Ca}^{2+}$ pump by a constant that involves different kinetic coefficients of the reaction cycle. Conversely, the apparent affinities and the turnover of the phosphoenzyme, unmodified by glycation, only involve kinetic coefficient ratios.

In this kinetic analysis, the simplest explanation for the effect of glycation on the $\mathrm{Ca}^{2+}$ pump is a decrease in the total amount of the active enzyme with no changes of the rate coefficients for the remaining active enzyme. Consequently, those enzyme molecules that have been inactivated by glycation do not subsequently hydrolyze ATP, cannot be phosphorylated, and do not transport $\mathrm{Ca}^{2+}$. In addition, they cannot hydrolyze pNPP in the ATP-dependent mode but can do it throughout the calmodulin-dependent cycle.

There is Only One Lysine Residue Involved in the INACTIVATION PROCESS

Glycation of proteins occurs through the nucleophilic addition of amino groups to the carbonylic function of glucose. The reaction partners of glucose are the $\alpha$ - 
amino terminal group and the $\varepsilon$-amino group of the side chain of Lys residues (Ledl et al., 1989). In the $\mathrm{Ca}^{2+}$ pump the N-terminal amino is blocked (Zvaritch et al., 1990), thus only the lysine residues could react with glucose. The main isoform of the erythrocyte $\mathrm{Ca}^{2+}$ pump, hPMCA4b (Strehler et al., 1990), has 83 lysine residues, 80 of them outside the membrane being targets for glycation.

In a previous work (González Flecha et al., 1993) we have demonstrated that glycation of the $\mathrm{Ca}^{2+}$ pump takes place along two phases: an early exponential phase and a linear, slower one. The inactivation of the enzyme by glucose presents the same time course as the early phase of the incorporation of glucose to the $\mathrm{Ca}^{2+}$-ATPase. On the other hand, the slow phase of glucose incorporation to the enzyme may be related with the glycation of amino groups that are only exposed in the thermally denatured state of the $\mathrm{Ca}^{2+}$ pump. Data in Fig. 5 demonstrate that inhibition proceeds concomitantly with the incorporation of glucose with a maximum of 5 moles per mole of pump ( $G L_{\infty}$ in Eq. 5). Since the stoichiometry of glycation is one mole of glucose per mole of amino group, this result implies a mean of five glycated Lys residues per mole of $\mathrm{Ca}^{2+}$ pump.

The probabilistic analysis of the relation between the fractional enzyme activity and the fraction of nonmodified residues (Fig. 6) indicates that out of 5 modifiable lysine residues, only one is involved in the inhibition process.

\section{Glycation Sites on the Calcium Pump}

The incorporation of $\left[6-{ }^{3} \mathrm{H}\right]$-glucose to the pump during the fast phase of glycation represents a short fraction $(6.5 \%)$ of the lysine residues of this protein. The unambiguous assignment within the primary structure of the pump of each peptide fragment obtained by digestion of the pump (Castello et al., 1997) allowed us to evaluate the amount of Lys residues in each peptide, which was about $0.6 \mathrm{mmol}$ of Lys per gram of peptide for all the peptides. Thus, the equivalence among the specific incorporation of glucose suggests a random distribution of labeling rather than a pattern of specific glycation sites. Further, our results showed that when the $\mathrm{Ca}^{2+}$ pump bound 2 moles of glucose per mole of enzyme, glucose was incorporated into at least five different regions of the protein.

In spite of the unselective incorporation of glucose to the pump, and the availability of 80 Lys residues, the maximal incorporation of glucose to the native $\mathrm{Ca}^{2+}$ pump was 5 moles of glucose per mole of pump. This result suggests that the unselective glucose incorporation into the pump proceeds through a self-limited mechanism as described for the glycation of other proteins
(Kowluru et al., 1989). This agrees well with the fact that the presence of ATP during glycation prevents the loss of $\mathrm{Ca}^{2+}$-ATPase activity leaving unaffected the degree of glycosylation of membranes (González Flecha et al., 1990). The eventual specificity of labeling in the Lys residue responsible of the inhibition with the consequent enrichment in the label bound to the fragments containing it, cannot be observed in our labeling patterns because of the high number of Lys residues available for glycation in each proteolytic fragment.

In summary, our results show that: (i) There is only one Lys residue involved in the inhibition by glycation of the plasma membrane $\mathrm{Ca}^{2+}$ pump. Glycation of this residue results in the total loss of the $\mathrm{Ca}^{2+}$-ATPase, ATPdependent phosphatase and $\mathrm{Ca}^{2+}$ transport activities, all of which include a site related to the ATP-binding domain. Additionally, glycation of the pump does not affect the calmodulin-dependent phosphatase activity. This activity pertaining to the pump does not imply the catalytic site, (Donnet et al., 1998), and involves the $\mathrm{E}_{2}-\mathrm{E}_{1}$ transition where transition towards $\mathrm{E}_{1}$ may occur through a futile cycle that hydrolyzes p-nitrophenylphosphate without eliciting $\mathrm{Ca}^{2+}$ transport. These results place constraints on how glycation inhibit the pump. It could be postulated that glycation reduces the ATP binding rate coefficient to zero. However, this reaction step does not take place during the calmodulin-dependent phosphatase activity. In this sense, the pattern of inhibition of the hPMCA4b by glycation is similar to that observed for the inhibition by FITC under controlled conditions (Muallem \& Karlish, 1983; Donnet et al., 1998).

(ii) Glycation of the $\mathrm{Ca}^{2+}$ pump involves the unselective glucose incorporation of five moles of glucose per mole of protein. The presence of ATP during glycation prevents the inactivation of the pump without modifying the incorporation of glucose (González Flecha et al., 1990). This fact suggests that the nucleotide competes with glucose for Lys residues in the catalytic domain but not for other nonessential Lys residues.

(iii) The $\mathrm{Ca}^{2+}$-ATPase activity measured in erythrocyte membranes or purified enzyme preparations preincubated with glucose depends on the remaining glycated enzyme molecules in which the Lys residue involved in ATP hydrolysis stays unglycated. The remaining ATPase activity does not show appreciable changes in the affinity for $\mathrm{Ca}^{2+}$, modulators or inhibitors of the pump.

(iv) Glycation of the $\mathrm{Ca}^{2+}$ pump proceeds through a self-limited mechanism. In this sense, a 100\% inhibition should demand treatments under more extreme conditions that should restrict the availability of Lys residues located outside the catalytic domain. Besides, incubation of ATPase molecules under drastic conditions enhances the possibility of thermal denaturation of the pro- 
tein. Therefore, a total inhibition of the $\mathrm{Ca}^{2+}$ pump by glycation is a very unlikely phenomenon.

Glycation of the $\mathrm{Ca}^{2+}$ pump may produce an imbalance in the erythrocyte transmembrane $\mathrm{Ca}^{2+}$ flux with an increment in the cytoplasmic concentration of the cation. Disorders of intracellular $\mathrm{Ca}^{2+}$ metabolism may play an essential role in both the pathophysiologic complications of diabetes and the associated abnormalities in the action as well as the secretion of insulin (Gagliardino \& Rossi, 1994). The $\mathrm{Ca}^{2+}$-ATPase alteration, which is easily demonstrable in a circulating cell, could be indirect evidence of a wide impairment of the enzyme function developed in cells chronically exposed to high glucose levels.

This research is dedicated to Professor A.C. Paladini on the occasion of his 80th birthday, April 4, 1999. This work was supported by grants from: UBACYT(TB 071), CONICET (PIP 0270), ANPCYT and Fundación Antorchas.

\section{References}

Back, J.F., Oakenfull, D., Smith, M.B. 1979. Increased thermal stability of proteins in the presence of sugars and polyols. Biochemistry 18:5191-5196

Brownlee, M., Vlassara, H., Kooney, A., Ulrich, P., Cerami, A. 1986. Aminoguanidine prevents diabetes-induced arterial wall protein cross-linking. Science 232:1629-1632

Carafoli, E. 1991. Calcium pump of the plasma membrane. Physiol. Rev. 71:129-153

Caride, A.J., Rossi, J.P.F.C., Garrahan, P.J., Rega, A.F. 1990. Does calmodulin regulate the affinity of the human red cell $\mathrm{Ca}^{2+}$ pump for ATP? Biochim. Biophys. Acta 1027:21-24

Castello, P.R., Caride, A.J., González Flecha, F.L., Fernández, H.N., Rossi, J.P.F.C., Delfino, J.M. 1994. Identification of transmembrane domains of the red cell calcium pump with a new photoactivatable phospholipidic probe. Biochem. Biophys. Res. Commun. 201:194-200

Castello, P.R., González Flecha, F.L., Caride, A.J., Fernández, H.N., Delfino, J.M., Rossi, J.P.F.C. 1997. The membrane topology of the amino-terminal domain of the red cell calcium pump. Protein Sci. 6:1708-1717

Donnet, C., Caride, A.J., Talgham, S., Rossi, J.P.F.C. 1998. Chemical modification reveals involvement of different sites for nucleotide analogues in the phosphatase activity of the red cell calcium pump. J. Membrane Biol. 163:217-224

Ellis, G.P. 1959. The Maillard reaction. Adv. Carbohyd. Chem. 14:63134

Gagliardino, J.J., Rossi, J.P.F.C. 1994. $\mathrm{Ca}^{2+}$ ATPase in pancreatic islets: its possible role in the regulation of insulin secretion. Diabetes Metab. Rev. 10:1-17

Gietzen, K., Wüthrich, A., Bader, H. 1981. A new powerful inhibitor of red cell $\mathrm{Ca}^{2+}$ transport ATPase and calmodulin-regulated functions. Biochim. Biophys. Res. Commun. 101:418-425

Glynn, I.M., Chappell, J.B. 1964. A simple method for the preparation of ${ }^{32} \mathrm{P}$ labeled adenosine triphosphate of high specific activity. Biochem. J. 90:147-149

González Flecha, F.L. 1996. [Alterations in the human erythrocyte calcium pump produced by non enzymic glycation] Estudio de las alteraciones producidas en la $\mathrm{Ca}^{2+}$-ATPasa de eritrocitos humanos por glucosilacion no enzimática. $\mathrm{PhD}$ Thesis: Universidad de Buenos Aires

González Flecha, F.L., Bermúdez, M.C., Cédola, N.V., Gagliardino, J.J., Rossi, J.P.F.C. 1990. Decreased $\mathrm{Ca}^{2+}$-ATPase activity after glycosylation of erythrocyte membranes in vivo and in vitro. Diabetes 39:707-711

González Flecha, F.L., Castello, P.R., Caride, A.J., Gagliardino, J.J., Rossi, J.P.F.C. 1993. The erythrocyte calcium pump is inhibited by nonenzymic glycation: studies in situ and with the purified enzyme. Biochem. J. 293:369-375

Horiike, K., McCormick, D.B. 1979. Correlation between biological activity and the number of functional groups chemically modified. J. Theor. Biol. 79:403-414

Kowluru, R.A., Heidorn, D.B., Edmondson, S.P., Bitensky, M.W., Kowluru, A., Downer, N.W., Whaley, T.W., Trewhella, J. 1989. Glycation of calmodulin: chemistry and structural and functional consequences. Biochemistry 28:2220-2228

Ledl, F., Beck, J., Sengl, M., Osiander, H., Estendorfer, S., Severin, T., Huber, B. 1989. Chemical pathways of the Maillard reaction. Progr. Clin. Biol. Res. 304:23-42

Lowry, O.H., Rosebrough, N.J., Farr, A.L., Randall, R.J. 1951. Protein measurement with the Folin phenol reactive. J. Biol. Chem. 193:265-275

MacFarland, K.F., Catalano, E.W., Day, J.F., Thorpe, S.R., Baynes, J.W. 1979. Nonenzymatic glucosylation of serum proteins in diabetes mellitus. Diabetes 28:1011-1014

Miller, J.A., Gravallese, E., Bunn, H.F. 1980. Nonenzymatic glycosylation of erythrocyte membrane proteins. Relevance to diabetes. J. Clin. Invest. 65:896-901

Monnier, V.M. 1989. Toward a Maillard reaction theory of aging. Progr. Clin. Biol. Res. 304:1-22

Muallem, S., Karlish, S.J.D. 1981. Studies on the mechanism of regulation of the red cell $\mathrm{Ca}^{2+}$ pump by calmodulin and ATP. Biochim. Biophys. Acta 647:73-86

Muallem, S., Karlish, S.J.D. 1983. Catalytic and regulatory ATPbinding sites of the red cell $\mathrm{Ca}^{2+}$ pump studied by irreversible modification with fluorescein isothiocyanate. J. Biol. Chem. 258: $169-175$

Neuhoff, V., Arold, N., Taube, D., Ehrhardt, W. 1988. Improved staining of proteins in polyacrylamide gels including isoelectric focusing gels with clear background at nanogram sensitivity using Coomassie Brilliant Blue G-250 and R-250. Electrophoresis 9:255262

Peterson, G.L. 1977. A simplification of the protein assay method of Lowry et al. which is more generally applicable. Anal. Biochem. 83:346-356

Rega, A.F., Garrahan, P.J. 1975. Calcium ion-dependent phosphorylation of human erythrocyte membranes. J. Membrane Biol. 22:313327

Richards, D.E., Rega, A.F., Garrahan, P.J. 1978. Two classes of site for ATP in the $\mathrm{Ca}^{2+}$-ATPase from human red cell membranes. Biochim. Biophys. Acta 511:194-201

Rossi, R.C. 1987. [Looking for the kinetic model of the Na,K ATPase] En busca del modelo cinético de la Na,K-ATPasa. PhD Thesis, pp. 38-56, Universidad de Buenos Aires

Rossi, J.P.F.C., Caride, A.J. 1991. Inhibition of the phosphatase activity of the red cell $\mathrm{Ca}^{2+}$ pump by acidic phospholipids. Biochim. Biophys. Acta 1061:49-55

Rossi, J.P.F.C., Garrahan, P.J., Rega, A.F. 1986. The activation of phosphatase activity of the $\mathrm{Ca}^{2+}$-ATPase from human red cells membranes by calmodulin, ATP and partial proteolysis. Biochim. Biophys. Acta 858:21-30 
Roufogalis, B.D., Villalobo, A. 1989. The $\left(\mathrm{Ca}^{2+}+\mathrm{Mg}^{2+}\right)$-ATPase. Purification and reconstitution. In: The Red Cell Membrane, A Model for Solute Transport. B.U. Raess and G. Tunnicliff, editors. pp. 76-83. Humana Press, NJ

Schägger, H., Von Jagow, G. 1987. Tricine-sodium dodecyl sulfatepolyacrylamide gel electrophoresis for the separation of proteins in the range from 1 to $100 \mathrm{kDa}$. Anal. Biochem. 166:368-379

Schatzmann, H.J., Roelofsen, B. 1977. Some aspects of the $\mathrm{Ca}^{2+}$ pump in human red blood cells. In: Biochemistry of membrane transport. G. Semenza and E. Carafoli, editors. pp. 389-400. Springer-Verlag, Berlin

Schwarzbaum, P.J., Kaufman, S.B., Rossi, R.C., Garrahan, P.J. 1995. An unexpected effect of ATP on the ratio between activity and phosphoenzyme level of $\mathrm{Na}^{+} / \mathrm{K}^{+}$-ATPase in steady state. Biochim. Biophys. Acta 1233:33-40

Seber, G.A.F., Wild, C.J. 1989. Nonlinear regression. Wiley, New York

Segel, I.H. 1975. Enzyme Kinetics. Behavior and analysis of rapid equilibrium and steady state enzyme systems. Wiley-Interscience, New York

Strehler, E.E., James, P., Fischer, R., Heim, R., Vorherr, T., Filoteo, A., Penniston, J.T., Carafoli, E. 1990. Peptide sequence analysis and molecular cloning reveal two calcium pump isoforms in the human erythrocyte membrane. J. Biol. Chem. 265:2835-2842

Tishler, P.V., Epstein, C.J. 1968. A convenient method of preparing polyacrylamide gels for liquid scintillation spectrometry. Anal. Biochem. 22:89-98

Tsuo, C.L. 1962. Relation between modification of functional groups of proteins and their biological activity I. A graphical method for the determination of the number and type of essential groups. Sci. Sinica 11:1535-1558

Vlassara, H., Brownlee, M., Cerami, A. 1986. Nonenzymatic glycosylation: role in the pathogenesis of diabetic complications. Clin. Chem. 32:37-41

Zvaritch, E., James, P., Vorherr, T., Falchetto, R., Modyanov, N., Carafoli, E. 1990. Mapping of functional domains in the plasma membrane $\mathrm{Ca}^{2+}$ pump using trypsin proteolysis. Biochemistry 29:80708076

\section{Appendix}

\section{Probabilistic Analysis of the Relation Between the Fractional Enzyme Activity and the Number of Nonglycated Lysine Residues}

As demonstrated in this work $\mathrm{Ca}^{2+}$-ATPase becomes inactive by reaction with glucose. This enzyme contains 80 glycable residues $(n)$; five of them $(p)$, including $i$ essential residues for the activity, can react with glucose with a pseudo-first order rate coefficient $k$ equivalent to the kinetic coefficient of the inactivation process, and 75 nonessential residues $(n-p)$ react with glucose with a pseudo-first order rate coefficient $k^{\prime}$ significantly different of $k\left(k^{\prime}=\alpha k\right)$.
At a given stage of reaction, the total fraction of nonglycated residues $(x)$ will be a function of the fraction of $p$ that remain unglycated $\left(x_{1}\right)$ and the fraction of $n-p$ that remain unglycated $\left(x_{2}\right)$.

$x=\frac{p \cdot x_{1}+(n-p) \cdot x_{2}}{n}$

The fractions of nonglycated enzyme $\left(x_{1}\right.$ and $\left.x_{2}\right)$ decrease with time according to a pseudofirst-order kinetics

$x_{1}=e^{-k \cdot t}$

and

$x_{2}=e^{-\alpha \cdot k \cdot t}=\left(e^{-k \cdot t}\right)^{\alpha}$

then, Eq. (A1) may be written as

$x=\frac{p \cdot x_{1}+(n-p) \cdot x_{1}^{\alpha}}{n}$

Assuming that glycation of any one of the essential residues fully inactivates the enzyme, the fraction of active molecules $\left(v_{r}\right)$ will be equal to the ratio

$v_{r}=\frac{\text { remaining enzymatic activity after glycation }}{\text { activity of the enzyme before glycation }}$

The fraction of glycated lysine residues in the enzyme molecule at a given reaction stage may be visualized as the probability of glycation. Thus, if the modification of each essential residue was an independent event,

$v_{r}=x_{1}^{i}$

According to equations (A2) and (A3), the number of nonglycated residues per molecule will be given by

$n \cdot x=p \cdot v_{r}{ }^{1 / i}+(n-p) \cdot v_{r}^{\alpha / i}$

dividing both sides of Eq. (A3) by $v_{r}{ }^{1 / i}$, and subtracting $p$ from both sides,

$\frac{n \cdot x}{v_{r}{ }^{1 / i}}-p=(n-p) \cdot v_{r}^{(\alpha-1) / i}$

and then,

$\ln \left[\frac{n \cdot x}{v_{r}{ }^{1 / i}}-p\right]=\ln (n-p)+\frac{(\alpha-1)}{i} \cdot \ln v_{r}$

The analysis consists in plotting the left-hand side in Eq. (6) against $l n$ $v_{r}$, for $i=1,2, \ldots, p$ and to find the value of $i$ that gives a straight line, as predicted by Eq. (6). 